Revista Iberoamericana. Vol. LXV, Núm. 187, Abril-Junio 1999; 359-371

\title{
ALBERTO RUY SÁNCHEZ, CALÍGRAFO DEL EROTISMO
}

\author{
POR \\ María del Mar Paúl Arranz \\ Universidad Europea de Madrid \\ María luisa de la Garza Chávez \\ Universidad Autónoma de Madrid
}

Nos proponemos en este trabajo analizar la obra de Alberto Ruy Sánchez (Ciudad de México, 1951), uno de los novelistas más interesantes que en la actualidad tiene México. De modo general puede afirmarse que su escritura se aleja de las tendencias narrativas más habituales en este país, tanto en temas y escenarios como en los perfiles de sus personajes; y su prosa, que constituye uno de sus hallazgos más originales, discurre por los caminos de la sensualidad y el erotismo con sutileza pero sin concesiones, logrando, con su fuerza poética y la plasticidad de sus imágenes, convertir al discurso en el protagonista verdadero y relegando la anécdota a un plano meramente instrumental.

Las dos novelas de las que vamos a ocuparnos, Los nombres del aire y En los labios del agua, ${ }^{1}$ recrean una peregrinación amorosa sin aparente destino. Sus personajes, impulsados por una fuerza que le pertenece a la naturaleza misma, se entregan ávidamente al logro de unos deseos que los poseen. Entre ambas obras se teje una complicada red de referencias y de intertextualidades temáticas y simbólicas, aunque sus puntos de partida sean radicalmente distintos: la primera nos narra la iniciación sexual de una adolescente, Fatma, y de paso nos ofrece un interesante e insólito recorrido por la sensibilidad femenina en su relación diversa con el mundo; la segunda es la historia de Juan Amado, un novelista mexicano que descubre, en los textos de un calígrafo marroquí, que su destino está trazado a la medida de los deseos inconclusos de otro.

Entre los elementos que comparten, destacan las figuras de la espiral y el laberinto, las referencias a la numerología y el lugar privilegiado que ocupa el contador tradicional de historias en la cultura árabe, o "halaiquí", especie de oráculo que, a la postre, nos revela los misterios de las respectivas tramas. Las dos responden, además, a un mismo diseño arquitectónico: una primera parte con nueve capítulos que son camino, búsqueda, viaje, y una segunda parte con cuatro capítulos más, en los que se reúnen los elementos dispersos y se descubren las informaciones sobre las que se había cimentado la intriga.

\footnotetext{
' Los nombres del aire fue publicada en 1987 y Alfaguara la reeditó en 1996, año en que también aparecería, en la misma editorial, En los labios del agua. A estas ediciones remiten todas las referencias, que para evitar confusiones irán seguidas en algunos casos de la iniciales de las respectivas novelas. Ruy Sánchez es autor, además, del relato Los demonios de la lengua, de los Cuentos de Mogador y de varios libros de ensayos, entre los que destacan Una introducción a Octavio Paz, Tristeza de la verdad: André Gide regresa de Rusia y Con la literatura en el cuerpo.
} 
Comparten también la existencia de Mogador, ese lugar imaginario que forma ya parte de la geografía literaria mexicana y que, aunque en origen está vinculado a Marruecos, se ha transmutado, para los lectores de Ruy Sánchez, en un jardín del tiempo en el que cabe todo aquello que pueda ser sentido como arrebatador. ${ }^{2}$ En este lugar sin lugar, se prescinde de las referencias cronológicas "objetivas" porque sólo lo significativo tiene relevancia, y para los personajes sólo es significativo lo que de forma directa o indirecta remite al objeto deseado. El tiempo se humaniza y el ritmo de la narración mimetiza ese tiempo interior en el que nos instalamos, porque responde a una tentativa de apropiación del devenir como experiencia, aunque ese devenir se reduzca a una lenta conversación con las cosas. Del tiempo universal, de "cronos", sólo se conservan los intervalos significativos, los kairós. ${ }^{3}$ Esto se refleja en una construcción narrativa fragmentaria, que nos da apenas destellos, instantáneas con las que hemos de ir elaborando los perfiles de los personajes y las circunstancias en que se desenvuelven.

Finalmente, en una concepción de la escritura que recuerda al rizoma de Deleuze y Guattari, los símbolos de Ruy Sánchez eslabonan regímenes distintos y establecen correspondencias entre dimensiones diferentes; ${ }^{4}$ por ello, lo que ocurre en el cuerpo repercute en la ciudad - que para todos sus habitantes es imagen del mundo-, y los movimientos de los astros sugieren caminos si se acierta a interpretarlos. Así por ejemplo, Fatma se siente "presa de una geometría implacable: era un punto con destino, una línea del arabesco universal; era un dibujo de espuma en el mar del deseo, una marea callada obedeciendo la luna" (71). En consecuencia, los personajes buscan entre los signos del mundo aquéllos que les revelen su propia identidad y la de quienes desean: el universo entero es una escritura que hay que descifrar. ${ }^{5}$

\footnotetext{
2 "Yo di a Mogador una configuración distinta, añadiendo construcciones, gestos, rituales de otras partes, (pero) lo que traté de conservar sobre todas las cosas es esa existencia del deseo como una atmósfera en la que todo y todos se mueven y piensan: imaginan, y, en el espacio creado por esa imaginación, actúan", diría en una entrevista con Alejandro González, incluida en Alfilo de las hojas, 359.

${ }^{3}$ A propósito de la relación entre el tiempo fenomenológico y el tiempo cosmológico, véase Paul Ricoeur, Tiempo y narración III. El tiempo narrado, donde analiza las posibles soluciones a esta aporía temporal: la que plantea la historia mediante la elaboración de un "tercer tiempo" propiamente histórico, las que proporciona la ficción mediante las "variaciones imaginativas" que opera sobre el tiempo y la que propone su poética de la narración, mediante el concepto de "identidad narrativa", que resultaría de la unión de las refiguraciones del tiempo que hacen tanto la historia como la ficción. Respecto de la distinción entre "cronos" como un tiempo indiferenciado y "kairós" como los intervalos cargados de sentido, véase $\mathrm{F}$. Kermode, El sentido de un final.

${ }^{4}$ Parece tener en mente sobre todo los principios de conexión y de heterogeneidad, por los que "cualquier punto del rizoma puede ser conectado con cualquier otro, y debe serlo. [...] Eslabones semióticos de cualquier naturaleza se conectan en él con formas de codificación muy diversas, eslabones biológicos, políticos, económicos, etc., poniendo en juego no sólo los regímenes de signos distintos, sino también estatutos de estados de cosas" (Deleuze 17).

${ }^{5}$ Idea ésta que Ruy Sánchez encuentra presente en las obras de otros escritores, como nos lo hace ver a propósito de Artaud o de los románticos alemanes. Del primero dice que constantemente aparecen en su obra menciones al mundo como un conjunto de signos que viven en desorden pero requieren ser descifrados. Y eso para Artaud - añade- "sólo es posible muy de vez en cuando, en instantes
} 
Pero vayamos por partes y detengámonos en primer lugar en Los nombres del aire, de cuya protagonista, Fatma, se ha apoderado una intrigante melancolía. Quienes la conocen se preguntan qué pudo haberla transformado, sin que puedan responderse con certeza. Su abuela Aísha, que percibe el cambio, le echa la baraja para descubrir lo que le ha robado la tranquilidad. "Dentro de ti - le dice - hay ahora un pájaro altivo que vuela solo y en silencio [...] Buscas algo que perdiste, pero que se ha apoderado de ti" (17-18). Le augura a continuación que estará muy cerca de lo que persigue, pero que no sabrá reconocerlo. A pesar de este vaticinio, la joven se empeñará en encontrar "al pájaro que imperioso hacía volar a sus aves secretas" (19). ${ }^{6}$

A partir de esta escena inicial, que en realidad contiene toda la historia, el relato se despliega en dos direcciones: hacia delante, desemboca en el cumplimiento del destino anunciado, y retrospectivamente, explica el origen de la desazón de Fatma. Sin embargo, nada de cuanto le sucede modifica su circunstancia ni desata acción alguna en el resto de los personajes - salvo por las especulaciones que provoca. Y esto no se debe únicamente a que el proceso que ha iniciado sea fundamentalmente interno, se debe también a que mucho de lo que ocurre en la novela sólo es evidente para el lector. Los lectores somos los únicos que sabremos del fracaso de su empresa - para Fatma misma pasará inadvertido el momento preciso del desencuentro con lo que busca-y los únicos también que conoceremos que su deseo tiene cuerpo y nombre de mujer: Kadiya.

En efecto, es el encuentro con esa mujer morena la causa de la transformación de Fatma; con él inicia un largo "viaje sin regreso, muy dentro de ella misma" (25), viaje que es principalmente la toma de conciencia de un cuerpo distinto. Su estar en el mundo se modifica al descubrir la sensualidad y, sobre todo, al asumir la aventura de dejarse llevar por esa nueva cualidad. Fatma se constituye entonces en el centro de una espiral de deseo que irá envolviendo a los seres y a las cosas; su percepción se exacerba y se desfiguran los contornos de la realidad, quizá porque, como dice Octavio Paz, "el deseo puebla al mundo de imágenes y, simultáneamente, deshabita a la realidad" (147). Observamos aquí otro doble movimiento, pero esta vez referido no al desarrollo de la anécdota, sino a la relación de la protagonista con su entorno. Por una parte, Fatma vive un alejamiento del mundo en tanto que se abstrae de lo que ocurre a su alrededor, pero por otra parte vive un acercamiento

mágicos donde los signos del universo se ordenan por un momento y nos es dado entender". Novalis, por su parte, hablaba de "una escritura secreta que lo permea todo pero que se niega a convertirse en clave fija y desaparece dejándonos las cosas de nuevo aisladas, sin gramática" (Diálogos con mis fantasmas 24-25).

"La arabista puertorriqueña Luce López-Baralt comenta esta novela en "El 'Simurg' de Alberto Ruy Sánchez", artículo en el que relaciona los símbolos del autor con los de la tradición mística musulmana, y vincula la búsqueda erótica de Fatma con la búsqueda del Dios interior: "El pájaro en vuelo solitario con el pico vuelto al aire es, en Fatma, su propia sensualidad lanzada a los cuatro vientos, pero también es, en la más pura tradición sufí, el alma extática en la búsqueda del Dios Interior [...] El ave del alma no admite compañía en su ardua búsqueda, y se deja fascinar por el canto del éxtasis mientras orienta su vuelo hacia el aire o la brisa que le trae la "oscura noticia" de Dios. [...] el pájaro del deseo de Fatma, contrapartida inesperada del "Simurg" de Attar". Respecto del manejo del discurso narrativo, dice que es "tan profundamente árabe que con él, Ruy Sánchez parecería estar hispanizando lo que los arabistas han llamado "estructura de anillo"” de los textos semíticos. 
en tanto que capta todo con mayor intensidad. Fatma mira como nunca había mirado, busca con sus manos historias ocultas bajo la superficie de las cosas y, con los oídos, los quejidos escondidos tras los ruidos de la ciudad. "Se había movido de sí misma, como si hubiera resbalado y al levantarse hubiera quedado al lado de su propio cuerpo" (53-54); es ya otra, u otras, si consideramos el carácter polisémico de la alteridad.

La figura de la espiral se repite insistentemente a lo largo de todo el relato: la concentricidad del vuelo del ave de la protagonista aparece en la disposición de las cartas que le echa la abuela y en la traza de la ciudad, cuya calle principal, llamada del Caracol, lleva en espiral desde las murallas hasta la plaza central donde se encuentran los baños públicos (que a su vez tienen estructura concéntrica) y los templos de las tres religiones que ahí conviven. La novela misma repite esta figura, cuyo centro, tanto arquitectónico como semántico, lo constituye el baño público, el "Hammam", espacio atemporal y, por ello, ajeno a todo rito constrictor y limitante:

Ninguna de las tres religiones mayoritarias en la isla ha logrado extender sus prohibiciones hasta el "hammam". Dentro de sus muros ninguna frase del Corán, del Talmud o de la Biblia puede ser pronunciada, mucho menos escrita y se supone que ni pensada. Las mujeres se cuidan de entrar siempre con el pie derecho y de salir con el izquierdo, como si tan sólo un paso fuera dado entre la entrada y la salida; asi sitúan al "hammam" fuera del tiempo. Por lo tanto el "hammam" tiene sus propias leyes [...] Lo que afuera es ilícito, dentro es tan inconsistente como una fruta cuya cáscara se diluye en el aire y no se sabe ya dónde comienza (49).

Ese espacio, si bien común para hombres y mujeres, no lo comparten simultáneamente $y$, en consecuencia, evita que se reproduzcan los papeles que unos y otros tienen asignados afuera. Aunque por la mañana las mujeres que lo ocupan lo llenan de risas agudas, de gritos, y por la tarde los hombres exageran sus tonos varoniles "como queriendo incrustar en los otros la erección de su presencia" (50), en el "hammam" los cuerpos se liberan de la esclavitud de los géneros, de las maneras aprendidas, de los pudores heredados; es entonces cuando, entregados al juego voluptuoso y catártico en el que se descubren todas las humedades que el placer encierra, es posible también abrirse a otras formas de vivir la sexualidad, pues "sus muchas habitaciones y fuentes desencadenan, mañana y tarde, los laberintos propicios a la existencia de los ánimos y los sexos intermedios" (50).

No podía ser sino en ese lugar donde Fatma conociera a Kadiya. Ahí había atendido por primera vez al llamado de su piel; ahí había descubierto su cuerpo y sólo ahí, entre muchos otros iguales aunque diferentes, pudo "ahuyentar a los estorbosos ángeles del pudor [...] que son capaces de hacer sentir desprovista de velos a la mujer de ropa más amurallada" (52). Una mañana, pues:

Los dedos pálidos de Fatma y los muy obscuros de Kadiya habían hecho crecer entre las dos un tupido bosque de ramas negras y blancas, entretegidas como ilegible caligrafía. Se habían conocido en silencio y se amaron en la ausencia de palabras: hablaban la luz y la humedad de sus cuerpos. Decían lo que con muchas palabras se llega poco a decir (73).

Pero Fatma pierde a Kadiya en un momento en que cierra los ojos. Recorre una y otra vez el "hammam" como recorrerá luego el puerto y la ciudad, mas no consigue encontrarla. 
Comienza así una peregrinación frustrada y frustrante que incluye por igual a hombres y a mujeres. Sin embargo, ni el adolescente que en un parque la ama presuroso ni aquella mujer que le pide gestos de varón calman sus ansias, y al cabo, desprecia por igual tanto las miradas lascivas del poderoso Amjrus como la cándida propuesta de matrimonio del joven pescador Mohammed. A este respecto es interesante destacar que Fatma considera esta propuesta de una obscenidad insoportable, "tal vez porque en ella estaba muy probablemente su futuro" (96). Es éste uno de los pocos momentos en los que adivinamos una conciencia que vincula a la protagonista con su realidad social: la de su ser de mujer y la de tener por ello una función determinada que cumplir. El rechazo de la vida que ellos significan es la única muestra de censura - si es que del desprecio puede deducirse una censura - a las convenciones establecidas. Probablemente, Fatma habrá de plegarse a una suerte que le viene impuesta, pero lo que ya no podrá ignorar en todo caso es la conciencia de sí que el deseo y el amor le han despertado - pues es imposible no amar lo que se desea-, ni podrá evadirse del impulso transgresor que imprimen. Y es que el amor, en efecto, implica siempre una transgresión si aceptamos, como nos advierte el mismo Paz, que "nos abre las puertas de un estado que escapa a las leyes de la razón común y de la moral corriente" (151). No obstante, no podemos llevar esta idea demasiado lejos, pues no parece que entre las pretensiones de Ruy Sánchez se halle la de socavar los pilares en los que se asienta la moral imperante ni las instituciones que la regulan.

Fatma es el vínculo principal entre estos personajes, pero no el único; ertre ellos se tienden otros lazos que pasan por los sueños, por transacciones económicase, inevilablemente, por la piel: Mohammed y Amjrus tienen un encuentro sexual en el "hammam", adonde habían llegado para bañarse y conversar sobre la venta de peces, y ambos "conocen" también a Kadiya, especialmente Amjrus, visitante habitual de los barcos prostíbulo que atracan todos los sábados en Mogador.

Por lo que se refiere a En los labios del agua, el tema es también la búsqueda del ser deseado, pero esta vez el autor nos introduce en un interesante juego de espejos en el que se explotan las capacidades del sueño y de la escritura como únicas vías para vencer las barreras del espacio y la temporalidad. Y así tenemos, por un lado, a Aziz Al-Gazali, "autor de muchas letras dibujadas y de varios libros", que cayó seducido de golpe una tarde en cierta plaza por la sonrisa de una mujer, Hawa, a quien ya no pudo dejar de mirar. Trazó con ella los arabescos más sublimes y dibujó por ella las letras más hermosas. Pero la muerte se la arrebató. Su deseo, sin embargo, no murió con ella, así que creó para Hawa un lugar privilegiado en sus sueños: un jardín de radicales caricias donde no lo podría volver a dejar. Su escritura, en el afán de retenerla, se consagró entonces a contar lo que vivía con ella mientras dormía, y de ahí resultó un libro: La espiral de sueños, especie de invocación mágica llena de imágenes delirantes. También escribió La inaccesible, un poema en prosa dedicado a Mogador; un curioso relato con una tal Fatma por protagonista titulado Los nombres del aire y el tratado erótico De lo invisible en el amor, con dos subtítulos: el primero, "Notas sobre la casta de Los Sonámbulos", y el segundo, "En los labios del agua". Aziz fue, en efecto, el fundador de la llamada casta de Los Sonámbulos, a la que pertenecen aquellos seres "poseídos por los deseos hambrientos de miles de otras personas que murieron antes de realizar sus sueños" (93), y es a ellos a quienes dirige particularmente sus escritos. 
Por otro lado tenemos a Juan Amado, novelista que se tropieza con algunos fragmentos de los textos de Aziz y queda intrigado porque encuentra en ellos correspondencias con su propia historia. Hurga en sus palabras y entrevé un espejo que lo mira, así que comienza a investigar los secretos de esa vida que presiente que algo le dirá de la suya. Descubre a un hombre que, además de dibujar letras de agua, creaba sueños que eran talismanes y exploraba los vínculos entre el deseo y las leyes matemáticas de probabilidad. Su pasión era indagar la manera en que vivimos dentro de las mentes de los otros, la forma en que sobrevivimos en los demás. Juan, que se va impregnando progresivamente del espíritu del calígrafo, llega a enamorarse incluso de su amada:

Escribo esto - dirá en algún momento- no sólo con curiosidad e identificación, sino también y muchas veces sobre todo con celos. Ya sé que es absurdo y ridículo tener pasiones por los sueños de otros, aunque parezcan también los nuestros. Pero los celos son, precisamente, los más atrevidos navegantes de los ríos turbios y agitados que unen sueños y realidades. Todavía recuerdo con qué emoción y agonía seguí paso a paso sus descripciones de cómo fue seducido por esa mujer. Pero también recuerdo con callada felicidad los testimonios que describen su propia muerte (35).

Hermanos y rivales en el tiempo de los sueños que no conoce presente ni futuro, Juan dirige sus pasos a Marruecos, donde espera encontrar otros manuscritos de Aziz. Va reuniendo materiales dispersos y lo que descubre es que toda su peripecia ha sido prefigurada, que no es más que una línea del caligrama que Aziz diseñó para seguir viviendo en otros su amor truncado. En Mogador, la ciudad del deseo, Juan encuentra su propia Hawa y materializa a su manera los sueños de Aziz. Pero así como "una buena pluma debe romperse cuando ha logrado escribir con certeza la palabra amor" (161), la mujer que en una noche ocupó todos los planes de su vida desapareció por la mañana, y lo hizo con los manuscritos, con su cartera y hasta con su reloj. Sólo una hoja de La espiral de sueños será, como la flor de Coleridge o la de Wells, la única prueba de que pudo ser real lo que parecía un delirio.

Llegados a este punto es hora ya de adentrarse en el análisis de la estética a la que obedecen estas obras y que es precisamente lo que, como decíamos al principio, distingue a su autor en el panorama actual de la literatura mexicana. En el plano más superficial, pero no menos significativo, Ruy Sánchez utiliza con profusión innumerables elementos de procedencia árabe. Su interés por la cultura islámica se remonta a un viaje iniciático que realizó en su juventud a Marruecos, en el que recuperaría territorios olvidados de su geografia interior y conocería costumbres, prácticas y ritos que constituyen hoy algunas de sus claves narrativas. ${ }^{7}$ De hecho, sus textos parecen continuar la tradición arabigoandaluza del $a d a b$, género que en una de sus obras se define como "tratado que es a la vez una narración y un poema, generalmente vividos, en gran parte, por el autor" (Los nombres 32).

\footnotetext{
${ }^{7}$ Ruy Sánchez reivindica una tradición que llegó a América fundida con lo español pero que ha sido ignorada, e incluso afirma, no sin cierta exageración, que "México es un país árabe que se desconoce" (En los labios 122).
} 
La escritura de Alberto Ruy Sánchez se inscribe en lo que él mismo ha denominado "prosa de intensidades", cuya principal característica es la búsqueda en la literatura de dimensiones poéticas ocultas en la cotidianidad. Por ello, da un tono profundamente lírico a su prosa. No se apoya en ideas o anécdotas, sino en imágenes que se superponen como olas y que más que desarrollar un argumento lo matizan. Como en un caleidoscopio, pocos elementos forman infinitas figuras, y es más importante lo que se percibe que la complejidad del truco que nos lo haga ver. El qué que busca la objetividad es sustituido por el cómo que busca la diferencia. No importa qué pasa sino cómo es sentido aquello que pasa, y, sobre todo, cómo su paso provoca en quien lo vive una transformación. Por eso, las realidades que nuestro autor crea son más bien ensoñaciones donde la ley la dictan los deseos y en las que los sentidos son el medio de conocimiento principal. No se trata de abandonar la razón, sino de explorar las razones de la sensibilidad, de entrever la geometría de las pasiones, por recordar el texto de Remo Bodei. Donde el deseo habita, no hay más realidad que la que concibe el propio desear, o al menos no resulta relevante para quien el deseo vive. ${ }^{8}$ En este sentido, no estamos ante las dicotomías tradicionales que distinguen realidad y fantasía, sueño y vigilia, exterioridad e interioridad; es en el espacio intermedio donde se mueve Ruy Sánchez, en la "Y" que es toda potencia y que pone en evidencia lo equívoco de la polaridad.

Estamos hablando, sin duda, de una narrativa en la que el ritmo es fundamental, pues la cadencia de las palabras es el equivalente en las páginas del flujo y reflujo de intensidades que se trata de recrear. Asimismo, estamos hablando de una narrativa perifrástica, redundante e inevitablemente lenta y obsesiva, que se entretiene en los detalles y recurre una y otra vez a los paralelismos. Las imágenes, como decíamos más arriba, nunca vienen solas, aparecen como en racimos en los que agua, aire, miradas, manos y sonidos - los cristales del caleidoscopio - forman interminables figuras y sirven lo mismo para hablar de la espera que de un encuentro sexual.

Por eso, el tratamiento que hace Ruy Sánchez de las escenas eróticas resulta también peculiar. Se separa de las usuales descripciones más bien descarnadas y directas en favor de las insinuaciones:

Dos miradas se cruzaron como los arcos de una bóveda diseñada tiempo atrás. Pero sus gestos se tejieron de otro modo: Fatma se alojó en una pasividad que pedía ser complacida, de la misma manera que un dibujo reposado en el fondo de una vasija pide ser descubierto y admirado al terminar de beber. Kadiya llegó hasta ella como una elaborada pero rápida caída de agua: una cascada en filigrana (Los nombres 72 ).

E incluso cuando nos refiere el sexo sin metáforas, lo hace de forma tan indirecta que pareciera negar su propia enunciación. Dice lo que no se dice y, al decirlo, nos narra lo no narrado:

\footnotetext{
${ }^{8}$ Roland Barthes advertía, en sus Fragmentos de un discurso amoroso, del sentimiento de ausencia o de disminución de la realidad que experimenta el sujeto amoroso frente al mundo (97), pero nosotros planteamos que en estas obras a la vez que se produce una ausencia, se genera una forma distinta de proximidad. El amor, que genera siempre espacios nuevos de convivencia, también produce un modo nuevo de habitar.
} 
[Aziz] no le dijo que quería devorarla, que quería sentir en la piel de su lengua cómo se transforman sus pezones. Que quería entrar en ella muy lentamente, como anunciándose más que estando, como yendo y viniendo más que penetrando, como convenciendo más que tomando. Ya no le dijo porque lo hizo. Y ella tampoco le dijo por dónde quería que pasaran sus manos, ni en qué momento iba a retenerlo por dentro con una fuerza que a ambos los rebasaba. Sus cuerpos eran los que hablaban, convencían, guiaban, cantaban y, por supuesto, bailaban. Tal vez alguien más en la calle los oía. Nadie dijo nada (En los labios 159).

Ante la imposibilidad de aprehender de una sola vez lo inaprehensible, prefiere rodearlo, presentar perspectivas distintas, decirlo en términos de una materia y después en términos de otra, para ver si en el cruce sinestésico, en la intersección de los campos semánticos, surge la figura, el movimiento o el estado que se quería describir.

Entras en mis oídos dibujando caracoles marinos: dentro llevo ya tus tormentas, tus ciclones, tus abismos. Tus voces bajan ya por mi garganta. Entras también en mis ojos con tu mirada: los tuyos tienen el color cambiante del agua. Entras en mi pecho con el tuyo: la piel protesta haciendo remolinos. En la orilla más baja de mi vientre tus caderas dejan, una y otra vez, la curva más violenta de tus olas: bañas mis playas, las golpeas y las devoras. Tu espuma y la mía se mezclan, como mis labios y los tuyos (En los labios 16-17).

Lo que fascina, lo que conmueve, lo que hace de una experiencia cualquiera algo singular, sólo puede ser descrito así, con imágenes circulares, pues es la única forma de objetivar, de "decir" la intensidad para que sea comunicable. Y en este intento de capturar lo esencialmente fugaz no hay ni moraleja ni costumbre; como dijo Klossowski, el sentido de la intensidad no es otro que el de ser pura intensidad."

La estética a la que obedece este tipo de narrativa no es ciertamente la más común en México, pero eso no quiere decir que carezca de precedentes. Como diría Borges, cada escritor escoge sus precursores, y Ruy Sánchez ha elegido los suyos. Entre ellos se encuentra el grupo de los Contemporáneos, que aparte de una extraordinaria obra poética, nos legaron también unos interesantes ejercicios en prosa. Fueron ellos los que, en consonancia con las corrientes de vanguardia de principios de siglo, hicieron hablar a la novela en primera persona, ensayaron con el punto de vista e hicieron diversos ejercicios de introspección; pero, sobre todo, abandonaron el descriptivismo, la discursividad y el concepto para entregarse a la imagen. La renovación que en su tiempo pretendían tenía que ver con la palabra y en buena medida con la abolición de las barreras entre los géneros. Fue así como "un día del siglo XX la novela se enamoró del poema". Esta frase de Gilberto Owen resume bien su práctica narrativa, que pretende fundamentalmente desdibujar los límites y

\footnotetext{
"Ruy Sánchez alude al desarrollo que hace Klossowski de la idea nietszcheana del sentimiento más elevado en su Diálogo con mis fantasmas. Por otra parte, en De cuerpo entero expone su pretensión de describir la intensidad desnuda "los paraísos e infiernos que experimentamos con tal profundidad que pudieran merecer ser invocados involuntariamente por nuestro cuerpo en su agonía" (30). Ahí mismo se refiere a la inevitable proximidad de esta emoción con la experiencia mística con la que también comparte el ser, hasta cierto punto, inefable.
} 
hacer del arte un espacio sin fisuras ni divisiones. ${ }^{10}$ En consecuencia, exigieron que sus obras fueran leídas con la misma actitud que la poesía, porque antes que nada las concibieron como "textos de goce", según la denominación de Barthes (El placer del texto 25).

La propuesta estética del grupo apenas tuvo en su momento continuadores, salvo en muy contadas excepciones, como los trabajos de José Martínez Sotomayor, que Ruy Sánchez precisamente rescata del olvido al reeditarlos. " En el prólogo que los acompaña, teoriza acerca de la prosa de intensidades y, al indagar en la ascendencia literaria de ese autor, se dota a sí mismo de una tradición, que se remontaría, por cierto, a la prosa romántica, especialmente la francesa, y, en español, al Modernismo.

Por todo lo anterior, y porque además, emparentándose con la tradición árabe, son como el $a d a b$ - a la vez narración y poema-, es difícil encontrar en las obras de Ruy Sánchez un tratamiento convencional de los elementos en los que habitualmente se asienta el género novelístico. Por ejemplo, no podemos hablar propiamente de un diseño de personajes, de caracteres, sino más bien de presencias, de corporeidades exentas en la mayoría de los casos de vinculaciones sociales o afectivas. Podría decirse que apenas tienen historia. Sus rasgos se desdibujan inmersos en la atmósfera evanescente que crea el discurso, porque el verdadero protagonismo no les corresponde a ellos. Son una encarnación del deseo o una forma de la pasión, que es en realidad de lo que se está hablando. Todos están sometidos a un proceso de literaturización que los anula en su individualidad y les reduce el margen de autonomía - aunque este margen, por supuesto, sea siempre fruto del juego ficcional. Esto es así incluso En los labios del agua, a pesar de estar narrada en primera persona. Unas cuantas pinceladas de los orígenes familiares de Juan sirven para justificar su primer interés por Aziz; sus aventuras amorosas, centradas en juegos eróticos muchas veces casuales, antes que definir su personalidad justifican su pertenecencia en la casta de Los Sonámbulos; $\mathrm{y}$, en otro orden, ni siquiera su propio relato, que acoge por igual textos del calígrafo de Mogador como largas exposiciones sobre el baile al margen de la trama, no dice mucho de su condición de escritor.

En unas obras construidas a base de voces, los seres que las habitan carecen de ella. El autor les niega toda posibilidad de expresar su conciencia sin intermediarios, o de llegar a cualquier forma de autoanálisis. Esto es particularmente notorio en la primera novela. La ausencia casi total de diálogo agranda su irrealidad no sólo porque, al excluirlo, el narrador modela y suplanta la identidad de cada uno de ellos, sino porque además cada novela contiene otras historias de indudable sentido simbólico pero cuyos narradores pocas veces son dueños de la experiencia que transmiten. Toda la información está sometida a filtros y a interpretaciones, no digamos ya cuando aparece el "halaiquí", depositario por excelencia de una memoria sin dueño. Puesto que toda vida se convierte en ajena cuando se narra, las

\footnotetext{
1" Véase para un análisis más amplio de sus característica y aportaciones, el artículo de María del Mar Paúl "Contemporáneos: la narrativa de un grupo de poetas". Respecto a esta fusión de los géneros, el propio Ruy Sánchez define la prosa de intensidades como una forma intermedia entre la novela y el poema (De cuerpo entero 33).

1 José Martínez Sotomayor (1895-1980) se da a conocer en 1930 con La rueca del aire. Después publicaría dos volúmenes de cuentos en la misma línea titulados Lentitud y Locura. Todos ellos fueron agrupados por Ruy Sánchez en un volumen significativamente titulado Trama de vientos, en 1987.
} 
historias que, como el agua "corren y se escapan de las manos, pueden tomar todas las formas posibles" (En los labios 19). Este es un factor de desencuentro entre los personajes: Fatma, por ejemplo, que escucha una tarde la leyenda de una niña cuya familia había sido asesinada y que posteriormente fue vendida como esclava a un prostíbulo flotante, no es capaz de descifrar que se trata de la historia de Kadiya, aunque al oírla sintiera como un cosquilleo en la memoria. El viento le había traído el vuelo del ave que buscaba, pero no había sabido distinguirlo. El vaticinio de la abuela se había cumplido. ${ }^{12}$

Por lo que se refiere en particular a los personajes femeninos, cabe observar algunas diferencias entre las dos novelas. Desde luego, en Los nombres del aire la mujer se constituye en tema absolutamente central. Sin embargo, no se trata, como decíamos, de pergeñar un carácter femenino ni de explicar sus procesos mentales, sino de figurarse una sensualidad desbordada y de dar fe de un modo de sentir que se agota en sí mismo. Y decimos de "figurarse" porque en esta novela Ruy Sánchez ha optado por un narrador en tercera persona, cuya posición respecto de Fatma es en todo momento ambigua. Unas veces se sitúa tan próximo a ella que tenemos pleno acceso a sus sueños, a sus anhelos, su ansiedad; otras, por el contrario, hace patente una insalvable lejanía. Los frecuentes "parece que" o "eso hacía pensar" para referirse a los "movimientos de su alma" son el reconocimiento, efectivamente, de que se narra desde un afuera irreductible. Como una más de las presencias vaporosas que describe, el narrador recorre espacios y personajes a la manera de un fantasma: atraviesa cuerpos y mentes sin poder aprehender lo que contempla.

Al mundo femenino están asociadas de modo recurrente una serie de imágenes relacionadas con el agua, lo húmedo, lo vaporoso y lo etéreo, y muy frecuentemente se identifican mujer y ciudad:

Cuando (los marinos) se alejan por mucho tiempo de su blanca ciudad flotando en el mar, una inquietud se va apoderando de ellos hasta que los vence y, guiados más por la nostalgia que por las estrellas, vuelven y encajan sus barcas de mástiles erectos bajo los arcos y las puertas de la muralla vibrante. Si el trayecto de regreso es largo, por la noche los asalta en el sueño la extraña imagen de una ciudad desnuda, como una amante esperando en un puerto. Color de luna, la piel humedecida de sus anhelos. [...] Mogador es una ciudad de voces que resuenan, y sus murallas son como labios que amplifican y modulan su canto. [...] Para los marinos que a lo lejos lo oyen es el anuncio de que la carne por fortuna es débil, y de que sus inquietudes, que hace poco eran ambiguas e inconsistentes, tomarán ahora un cuerpo deleitable; como almas que vagaron puras y perdidas y que, por descuido de su destino, reencarnan gozosas en un momento de lujuria verdadera (Los nombres 45-46).

Las mujeres de En los labios del agua sólo son eslabones de la cadena que llevará a Juan Amado hasta Hawa; son mujeres-objeto que forman parte de la carrera de relevos amorosos del protagonista. Eso sí, son muy independientes, y en un par de ocasiones

\footnotetext{
${ }^{12}$ Es especialmente paradójico este ocultamiento de la palabra directa cuando es clara la voluntad de dejar patente la oralidad en la cultura árabe. No sólo el halaiqui cuenta historias de viva voz; lo hacen varios personajes secundarios, que con un pretexto mínimo reúnen en torno suyo a un grupo de personas que los escuchan. Asimismo, se transmiten de boca en boca recetas y consejos para, por ejemplo, retener a un marido.
} 
previenen a Juan de la tentación de caer en actitudes posesivas, pues “el ave del deseo seguirá siempre volando [...] aunque ahora esté un instante en (tus) manos" (85). Como afirma el Levinas de El tiempo y el otro, sólo si el eros difiere de la posesión y el poder es posible la comunicación erótica. Todas ellas son sujetos deseantes que practican sin restricciones su libertad sexual, y algunas se reconocen como miembros de la casta de Los Sonámbulos. ${ }^{13}$ Se las ve repartir sus caricias por igual tanto a Juan como a otras mujeres, pero con una actitud y en unos ambientes que resultan un tanto inverosímiles. Todas están ligadas de alguna forma al mundo literario o musical (pues la casta parece tener un extraño predicamento entre los artistas), prácticamente todas son negras o mulatas y ninguna se plantea objeción alguna para amar a Juan. Incluso Maimuna, una africana a quien conoce en un salón de baile de Zacatecas, le dice:

Con él —refiriéndose a quien en breve tiempo sería su marido— todo es perfecto. Quiero hacer mi vida con él, sin duda. Nos amamos y nos deseamos sin límites. Incluso hacemos el amor maravillosamente. Pero él no es un apasionado del sexo, como tú y como yo. Entre nosotros, los que tenemos esta pasión, hacer el amor tiene otra dimensión. No se puede renunciar a esto (71).

A ti te quiero más pero a él desde hace más tiempo - le confiesa en otro momento. Tú estás mejor que nadie en el instante, en la intensidad. Él en mi historia. Tú y yo no tenemos futuro, tenemos apariciones mágicas fuera del tiempo. Instantes. Pueden ir y regresar (102).

Estas mujeres son, en definitiva, personajes encerrados en episodios sin continuación; existen en tanto que son útiles para resaltar las cualidades sonámbulas del protagonista, pero no obedecen a una necesidad argumental.

Otro de los procedimientos de que se vale Ruy Sánchez para teñir de irrealidad sus narraciones es el juego de equívocas autorías y falsas atribuciones. En los labios del agua en particular crea una intrincada estructura de cajas chinas, que combina con la alternancia de dos voces: la del escritor protagonista y la del calígrafo de Mogador. Además de apropiarse de los sueños de Aziz, Juan se apropia de su escritura, puesto que en buena parte nos la transcribe; pero a su vez, la escritura de Aziz contiene a Juan en tanto que prefigurado para cumplir sus deseos. No debemos olvidar tampoco que se afirma que Aziz es el autor de Los nombres del aire, obra que supuestamente Juan recibe de manos de otra sonámbula, Leila.

Me había interesado su búsqueda, sus sensaciones, su curiosidad por el mundo de las mujeres - comenta al principio de la novela. Como complemento al mostrar las huellas de Aziz y las mías, yo estaría explorando un mundo de fantasmas masculinos, siempre temerosos del vacío (En los labios 20).

\footnotetext{
${ }^{13}$ La casta de Los Sonámbulos es más que una sociedad secreta o una secta, es ante todo naturaleza y destino. En el libro, Los Sonámbulos son definidos de muy diversas maneras: "buscadores insaciables de ser amados" (En los labios 38) y "habitantes torpes de sus deseos y de sus sueños" (En los labios 39), por ejemplo.
} 
Asimismo, se le atribuye la propia escritura de Juan, pues en cierto sentido éste solamente "actualiza" aquella "peregrinación amorosa" hacia Hawa que era el Tratado de lo invisible en el amor. Como la espiral de sueños de Fatma, como el deseo que "es una flecha que avanza en círculos concéntricos" (En los labios 60), la estructura rizomática de las novelas de Alberto Ruy Sánchez propaga ecos y acumula reminiscencias y permite que las imágenes, los símbolos y los estilos se fundan y se confundan.

La espiral se ensancha y alcanza, evidentemente, a Ruy Sánchez, que de forma implícita también se reconoce miembro de la casta de Los Sonámbulos. ¿Abarca también a los lectores? Si el Tratado de lo invisible en el amor es En los labios del agua, y Juan fue completando con su experiencia aquellos fragmentos originales de Aziz, Ruy Sánchez parece decirnos que su novela aspira a ser fragmento de los textos que, como sonámbulo, elabore cada lector. En este sentido, constituye una invitación a dislocar el tiempo cotidiano, a desplazarnos de nosotros mismos y a ensayar la alteridad que, si es verdadera, produce alteración.

Aziz, como Ruy Sánchez, convoca a la experiencia de la intensidad, que puede darse primordialmente en el amor y en la figuración escrita del deseo, es decir, en la literatura. Ello implica tener disposición a poner-se en juego, a dar-se otros sentidos desde el poder-ser, que siempre es algo distinto de lo ya sido. Nuevas caricias como nuevas lecturas, nuevos amores como nuevas interpretaciones. Porque la transformación ha de pasar siempre por otro como la Kadiya de pechos vibrantes o la Hawa de cuerpo de papel--, que nos hará volver refigurados y, tal vez, transfigurados. Inevitablemente también poblados de ausencias, porque somos finitos, porque toda escritura cierra el cerco que ata el tiempo y porque es inmanente al gozo la fugacidad; pero principalmente porque, diría Derrida, el ser no es pura presencia: el ser es sobre todo ausencia del ser del otro.

En cualquier caso, lo que Alberto Ruy Sánchez parece querer decirnos con el complejo entramado de universos ficcionales de Juan y de Aziz es que la escritura es la forma más efectiva de apresar nuestros paraísos e infiernos, y él mismo así lo ha hecho: estas novelas son sin duda su intento de preservar lo que Octavio Paz llamara "nuestras raciones de eternidad" (citado por Ruy Sánchez en De cuerpo entero 32).

\section{Bibliografía}

Barthes, Roland. El placer del texto y lección inaugural. México: Siglo XXI, 1995.

Fragmentos de un discurso amoroso. México: Siglo XXI, 1993.

Bodei, Remo. Geometría de las pasiones. Miedo, esperanza, felicidad: filosofia y uso político. México: Fondo de Cultura Económica, 1995.

Deleuze, Gilles y Félix Guattari. Rizoma. Valencia: Pretextos, 1997.

Kermode, F. El sentido de un final. Madrid: Gedisa, 1980.

Levinas, Emmanuel. El tiempo y el otro. Barcelona: Paidós-I.C.E de la Universidad Autónoma de Barcelona, 1993.

López Baralt, Luce. "El "Simurg" de Alberto Ruy Sánchez". Vuelta 135 (México, febrero de 1988): 59-61. 
Martínez Sotomayor, José. Trama de vientos. México: Editorial Offset, S.A., 1987.

Paúl Arranz, María del Mar. "Contemporáneos: la narrativa de un grupo de poetas". Cuadernos Hispanoamericanos 53-54 (julio-agosto, 1996): 255-269.

Paz, Octavio, "La palabra edificante". Los signos en rotación y otros ensayos. Madrid: Alianza, 1991. 129-157.

Ricoeur, Paul. Tiempo y narración III. El tiempo narrado. México: Siglo XXI, 1996.

Ruy Sánchez, Alberto. Diálogo con mis fantasmas. México: Difusión Cultural UNAM, 1997.

En los labios del agua. Madrid: Alfaguara, 1996. Con la literatura en el cuerpo. Madrid: Taurus, 1995. Cuentos de Mogador. México: CNCA, 1994. De cuerpo entero. México: Ediciones Corunda-UNAM, 1992. Tristeza de la verdad: André Gide regresa de Rusia. México: Joaquín Mortiz, 1991. Una introducción a Octavio Paz. México: Joaquín Mortiz, 1990. Al filo de las hojas. México: SEP-Plaza y Valdés, 1988. Los nombres del aire. Madrid: Alfaguara, 1987. Los demonios de la lengua. México: Cuadernos de La Orquesta, 1987. 
